\title{
Energy Trade and Economic Integration between the Commonwealth Independent States and China
}

\author{
Ehsan Rasoulinezhad ${ }^{1+}$ \\ ${ }^{1}$ University of Tehran, Iran
}

\begin{abstract}
The main purpose of this study is to conduct the traditional economic, political, and geopolitical factors to uncover the relationship between different factors and the volume of China's energy importing from the Commonwealth of Independent States. We conducted a panel data framework for our sample during the period between 2001 and 2017. My paper's main findings reveal that the economic sizes of Commonwealth of Independent States members have a positive effect on China's energy import flow from the Commonwealth of Independent States. Furthermore, the amount of the Commonwealth of Independent States 's annual energy exports to countries other than China has a significant negative effect on the level of China's energy imports from the Commonwealth of Independent States. In regard to geographic distance, findings showed a negative sign of its coefficient meaning that geographical distance might decelerate energy trade flows running from the Commonwealth of Independent States to China. I also discovered that China's foreign direct investment in Commonwealth of Independent States states might determine and accelerate energy export flows running from the Commonwealth of Independent States to China. Finally, our major findings proved the evidence of a positive relationship between political risk in the Commonwealth of Independent States and the energy importing flows of China.
\end{abstract}

Keywords: Energy Exports; Influencing Factors, China, the CIS Region.

\section{Introduction}

Trade is one of the main instruments that can be utilized to promote economic integration between countries. Balwin and Venables (1995) believe that countries can establish significant economic ties through bilateral and multilateral trade. Soete and Van Hove (2017) state that trade flows between countries can mobilize culture, labor, capital, knowledge, etc., which improves economic cooperation and integration.

China is one of the biggest world energy consumers and plays a remarkably important role in global energy trade flows. According to the British Petroleum Energy Outlook of 2018, China's primary-energy consumption increased from 202 million Ton of Oil Equivalent (TOE) in 1970 
to 2,491 million TOE in 2010, and it can be predicted that it will rise to over 4,300 million TOE by 2040. Figure 1 presents a comparison between primary-energy consumption in China and various other regions between 1970 and 2040.

Figure 1. Primary-energy consumption by region

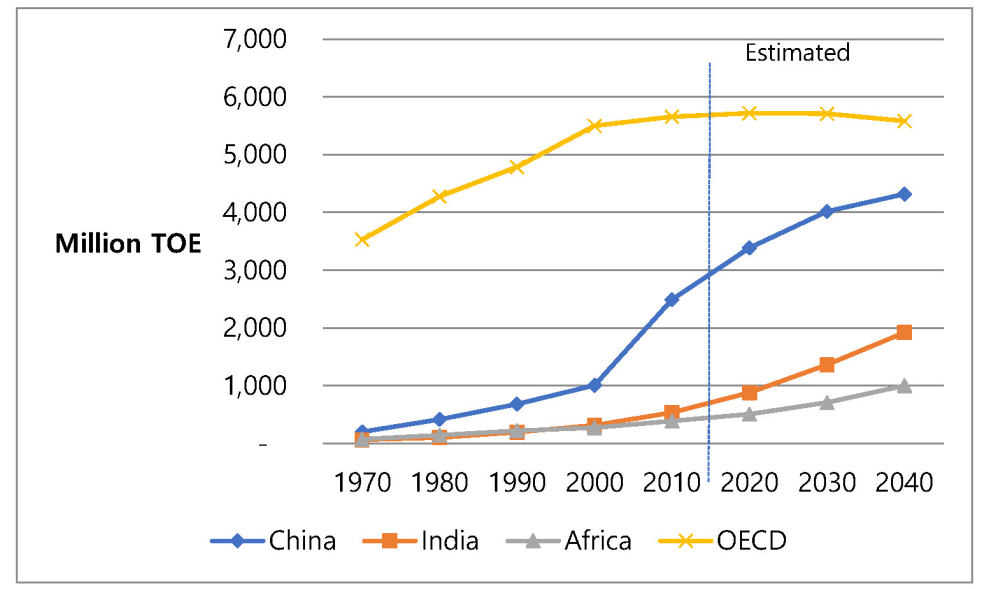

(Source) Author's compilation from the British Petroleum Energy Outlook 2018.

As it is shown in Figure 1, China is experiencing a sharp increase in energy consumption caused by its rapid industrialization and urbanization (Shao et al. 2017). The speed of China's industrialization and urbanization has led to an increase in its energy consumption, which has a direct impact on China's dependence on importing energy from different regions. Adams and Shachmurove (2008) argue that by 2020, China will require rapidly increasing imports of oil, coal, and gas. Notably, this growth in energy consumption is not very sensitive to China's rate of economic growth.

On the basis of Figure 2, according to the Trade Map database, China's energy import volume in four primary-energy harmonized codes $(2709,2711,2701$, and 2716) increases from 13,227 million US dollars to nearly 215,734 million US dollars, in 2001 and 2017, respectively. Moreover, it can be seen from Figure 2 that crude oil (HS code 2709) makes the largest contribution to China's energy imports volume, whereas electrical energy (HS code 2716) accounts for the lowest share of China's worldwide energy imports.

Among all energy producers, as a large, potential, nonrenewable energy exporter, the Commonwealth of Independent States (CIS)-which was created to manage the collapse of the Soviet Union (Kubicek 2009)-has considerable advantages in conducting energy trade with China. Apergis and Payne (2010) consider the CIS region, dominated by Russia, one of the largest and most influential oil and natural gas exporters in the world, has significant potential to be a reliable energy provider for neighboring energy importers, particularly for China, which shares 
a common geographical border with some of the CIS member states (i.e. Russia Kazakhstan Tajikistan and Kyrgyzstan). Furthermore, Chinese energy imports from Central Asia can contribute to increasing Chinese energy security levels as well as those from East Asia. Qiang and Xing-Kaing (2009) discuss Chinese energy strategy, and that diversification of their energy imports from different regions will enable China to shore up its energy security. To this end, the CIS region can become a key player in ensuring China's energy security. This argument aligns with Taghizadeh-Hesary. (2013), Taghizadeh-Hesary et al. (2019), and Rasoulinezhad et al. (2019), who all mention the importance of diversifying energy imports to ensure energy security in Asia. Consequently, securing the supply of energy might also contribute to increasing agricultural supply and food security (Taghizadeh-Hesary et al. 2019), which is an important goal for the current Chinese economy.

Figure 2. Energy imports volume of china, 2001 2017 (in thousands of US dollars)

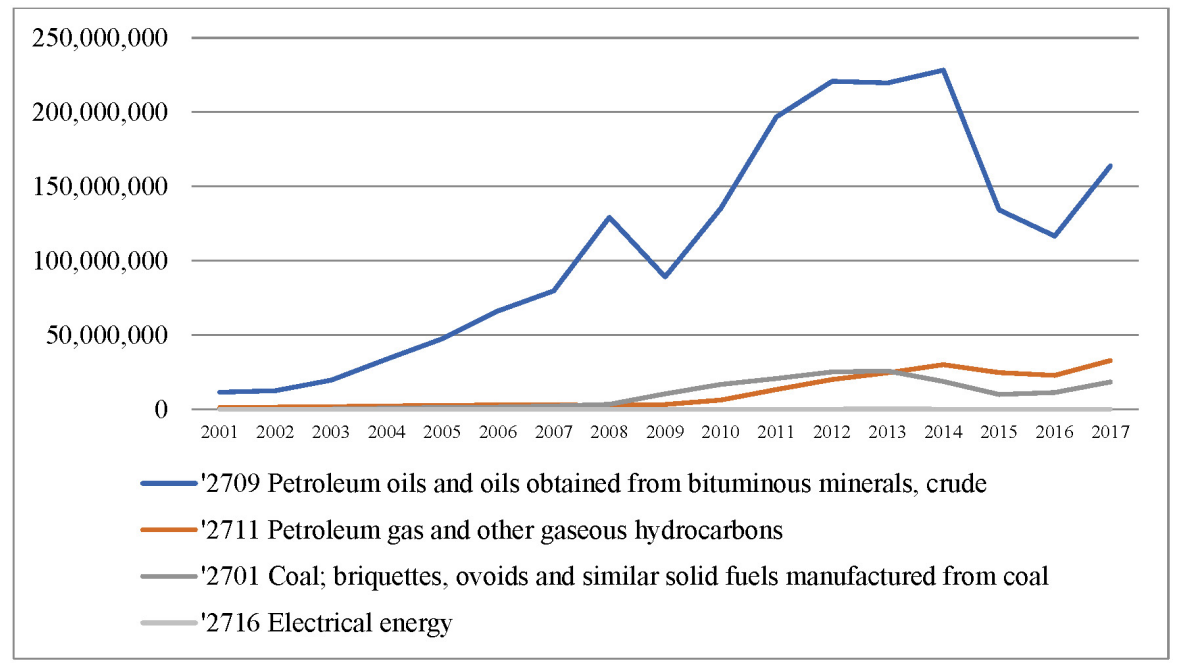

(Source) Author's compilation from TradeMap.

Table 1 reports statistics regarding energy trade flows running from the CIS to China during the period between 2015 and 2017. It is evident that petroleum oil and oil obtained from bituminous minerals (HS code 2709) dominate energy trade flows. In 2017, China's imports of this commodity from the CIS comprised $19.2 \%$ of total CIS energy exports worldwide and nearly $15 \%$ of total Chinese energy imports worldwide. It is interesting to note that imports of electrical energy (HS code 2716) from the CIS are very important for China. Contributions of China's electrical energy imports from the CIS to its total electrical energy imports from other countries were 52\%, 48.5\%, and $44.8 \%$ in 2015, 2016, and 2017, respectively.

Table 1 presents data for energy trade flows running from the CIS to China during the 2015 2017 period. 
Table 1. Energy trade from the CIS to china, 2015 2017 (in millions of US dollars)

\begin{tabular}{|c|c|c|c|c|c|c|c|c|c|c|}
\hline \multirow[b]{2}{*}{ Year } & & \multicolumn{3}{|c|}{$\begin{array}{l}\text { China's } \\
\text { energy imports } \\
\text { from CIS }\end{array}$} & \multicolumn{3}{|c|}{$\begin{array}{l}\text { Contribution of China's } \\
\text { energy imports from } \\
\text { CIS to CIS's energy } \\
\text { exports to the world }\end{array}$} & \multicolumn{3}{|c|}{$\begin{array}{l}\text { Contribution of China's } \\
\text { energy imports from } \\
\text { CIS to its energy } \\
\text { imports from the world }\end{array}$} \\
\hline & & 2015 & 2016 & 2017 & 2015 & 2016 & 2017 & 2015 & 2016 & 2017 \\
\hline \multirow{4}{*}{$\begin{array}{c}\text { HS } \\
\text { code }\end{array}$} & 2709 & 19,281 & 18,097 & 25,313 & $15.2 \%$ & $17.9 \%$ & $19.2 \%$ & $14.3 \%$ & $15.5 \%$ & $15.4 \%$ \\
\hline & 2711 & 8,257 & 6,380 & 7,603 & $13.9 \%$ & $46.9 \%$ & $13.9 \%$ & $33.1 \%$ & $27.7 \%$ & $23 \%$ \\
\hline & 2701 & 1,046 & 1,124 & 2,238 & $10.4 \%$ & $12.1 \%$ & $15.8 \%$ & $10.3 \%$ & $9.7 \%$ & $12 \%$ \\
\hline & 2716 & 175 & 155 & 139 & $15.4 \%$ & $15.2 \%$ & $12 \%$ & $52 \%$ & $48.5 \%$ & $44.8 \%$ \\
\hline
\end{tabular}

(Note) The numerals 2709, 2711, 2701, and 2716 are HS codes and indicate "Petroleum oils and oils obtained from bituminous minerals, crude," "Petroleum gas and other gaseous hydrocarbons," "Coal; briquettes, ovoids, and similar solid fuels manufactured from coal," and "Electrical energy," respectively.

(Source) Author's compilation from TradeMap.

According to the importance of the energy trade between the CIS and China, which may enhance their economic integration, the main question of this research is "which and what economic factors affect the CIS-China energy trade as a link to their economic integration?" Despite the existence of some academic studies such as Golobokov (2015), Orlov (2016), and Malle (2017), I did not find any similar research, a fact that supports the novelty of this study.

To conduct this research and answer the main question, I employ an econometric model using a panel framework over the period between 2001 and 2017. The variables are based on the traditional, economic, political, and geopolitical (TPG) factors introduced by Shao et al. (2017). The findings reveal the significant effects of TPG factors on the energy trade between the CIS and China, which also provides implications regarding their effects on China-CIS economic integration.

The remainder of this paper is organized as follows. First, Section 2 provides a brief review of the relevant literature. Next, Section 3 presents information regarding the study's data and methodology. Section 4 discusses the empirical results, and the last section concludes the paper.

\section{Literature Review}

The trade flows between CIS member states and China, especially in the field of energy, have recently been drawing the attention of a number of scholars. Some studies such as Chenard (1994), Davis (1997), Kandogan (1999), Roberts and Wehrheim (2001), and Sergi (2018) argue that foreign trade development is an essential policy for CIS member states because it enables them to improve their production capacities, promote their national commodities, and diversify commodities in their local markets. Moreover, several scholars, such as Lin and Wang (2012), 
Ge and Fan (2013), Dong and Kong (2016), Li et al. (2017), and Zou et al. (2018), explain that rapid economic development in China caused a sharp increase in energy demand, leading to a higher volume of worldwide energy imports. The need to expand CIS' foreign trade and the high Chinese demand for energy imports makes energy trade between China and CIS member states possible. Hirschhausen and Waelde (2001) investigated energy sector reforms in Eastern Europe and the CIS. The major result of this study was the conclusion that these nations will reach a high level of energy integration with big economies such as China. This will enable them to quickly develop their energy sectors as well as increase export revenues. Kakachia (2011) posited that the CIS region has become the focus of considerable international attention due to its energy production potential. In line with this finding, Kubicek (2013) believed that because of its geographical situation, China might be in the best position to fully leverage the energy capacity of the CIS region. He concluded that the CIS region offers an attractive market and source for investment. Its security norms also correspond well with central Asian government priorities. However, the power of CIS member states in energy markets and energy exports to China differs significantly. Newnham (2011), Nurgaliyeva (2016), and Bastsaikhan and Dabrowski (2017) argued that after the collapse of the Union of Soviet Socialist Republics (USSR) in 1991, Russia has tried to dictate the terms of energy volumes and prices to other CIS members, indicative of its dominance in the energy sector of the CIS region. However, this fact does not lower the potential of other CIS member states to independently develop their energy sectors. For instance, Karatayev and Clarke (2014) expressed that Kazakhstan under the shadow of Russia has eliminated many different technical, institutional, social, and economic barriers and is developing remarkable energy trade capacities. In another study, Vidadili et al. (2017) discussed the energy export development of Azerbaijan in the region. In the early 1990 s, this country followed a strategy of exploration and exploitation of carbon hydrogen resources in the Azerbaijani sector of the Caspian Sea. In order to provide safer export routes for the energy resources of Azerbaijan to world markets, they oversaw the construction of pipelines and became the transit country for the exportation of central Asian countries' energy resources. The importance and capacity of the energy sector in other CIS member states is addressed by Valigholizadeh et al. (2013) for Armenia, by Liu and Pistorius (2012) for Kyrgyzstan, and by Chomakhidze et al. (2017) for Georgia.

The next group of literature focuses on the factors affecting trade patterns. Howell and Chaddick (1994) tried to discover whether political risk affects foreign investment and trade. They found out that it depends on profit and loss consequences for businesses. Oh and Reuveny (2010) discussed how political risk reduces trade flows in importer and exporter countries. Dimic et al. (2016) investigated the effect of political risk on trade flows. The major findings asserted that the political risk effect originates in emerging economies, whereas it is not evident in developed countries. In another study, Braga-Alves (2018) argued that an increase of political 
risk levels leads to an increase in trade risk between countries, which ultimately reduces trade flows. Another important factor influencing trade flows between countries is economic growth, as indicated by annual changes in the GDP. Korhan et al. (2015), in line with Alesina et al. (2000), Bond et al. (2005), and Zahonogo (2016), mentioned that a higher economic growth rate indicates a better performance of the national economy, which accelerates trade flows. Zahanogo (2016) believed that by developing the size of an economy, trade flows enable a country to more fully capture the potential benefits of increasing returns to scale and economies of specialization. Besides economic size, geographical distance also plays a major role in determining the volume of trade flows. Rasoulinezhad and Kang (2016) proved that geographical distance as a proxy for transportation costs negatively affects trade flows between countries. The negative impact of geographic distance on trade flows between nations have been proven by many scholars such as Black (1973), Melitz (2007), Chen (2015), Jabalameli and Rasoulinezhad (2018), Rasoulinezhad (2019), and Rasoulinezhad and Jabalameli (2019). Moreover, numerous studies discussed the relationship between Foreign Direct Investment (FDI) and trade flows. For instance, Liu et al. (2001) discovered a positive relationship between FDI and trade in China. Aizenman and Noy (2006) proved that there are bi-directional linkages between FDI and trade. He et al. (2009) investigated the relationship between the American and Japanese FDI into China and the growth of the US trade deficit with China. The results indicated that an increase of FDI by the US in China led to a boost in China's exports to the US. Szkorupova (2014) showed that FDI improves the production capabilities of a nation, which leads to an increase in trade flows with other countries.

My paper contributes to the earlier literature by expressing the following points. The first important point is that this study is the first trade study that considers the determinations of the CIS's energy export flows to China. Considering that most prior studies conducting gravity trade model suffered because of the inclusion of variables in a rational framework, TPG factors are employed in this research to uncover the relationship between various factors and China's energy importing volume from the CIS. TPG, a framework proposed by Shao et al. (2017), integrates a series of factors that influence trade flows between nations into the model.

\section{Data and Research Methodology}

This research includes as the independent variable energy export volume from the CIS (which consists of eight member countries including the Russian Federation, Kazakhstan, Ukraine, Belarus, Azerbaijan, Uzbekistan, Turkmenistan, and Kyrgyzstan)1) to China over the period

1) - I only considered the CIS members who export energy sources to China. Hence, Georgia, Moldova, Armenia, and Tajikistan, which did not export any energy commodities to China, are not in our list. 
between 2001 and 2017. This period was chosen on the basis of China's participation in the World Trade Organization in 2001, which was the starting year of China's regional and global economic integration. To analyze energy export patterns between the CIS and China, I specify energy export $(E N E X)$ in thousands of US dollars. This variable contains five HS codes-2790: petroleum oils and oils obtained from bituminous minerals, crude; 2701: coal, briquettes ovoids, and similar solid fuels manufactured from coal; 2716: electrical energy; 2711: petroleum gas and other gaseous hydrocarbons; and 2710: petroleum oils and oils obtained from bituminous minerals. In addition, I follow Shao et al. (2017) in terms of explanatory variables by using the exporter's GDP in thousands of US dollars, the exporter's annual energy exports quantity to the world $(E N E X W)$ in thousands of US dollars, geographic distance from China (GDIS) in kilometers, China's FDI in thousands of US dollars, and the exporter's political risk $(P R)$. These definitions, units, and the sources of series data are represented in Table 2.

Table 2. Description of variables

\begin{tabular}{llll}
\hline Variable & \multicolumn{1}{c}{ Definition } & \multicolumn{1}{c}{ Units } & \multicolumn{1}{c}{ Data Sources } \\
\hline ENEX & CIS's energy exports to China & thousands of US dollars & Trade Map \\
GDP & The exporter's GDP & thousands of US dollars & World Bank \\
ENEXW & The exporter's annual energy exports quantity to the world & thousands of US dollars & Trade Map \\
GDIS & Geographic distance from China & kilometers & CPII database \\
FDI & China's direct investment in the exporter & thousands of US dollars & Statistical bulletin of \\
& & & China's outward FDI \\
PR & The exporter's political risk & - & World Bank \\
\hline
\end{tabular}

(Source) Author's compilation.

In this paper, I adjust the model used by Shao et al. (2017) for this analysis. On the basis of their econometric panel model, which contains (TPG) variables, and the series, my panel equation is thus given by the following:

$$
\begin{aligned}
\ln E N E X_{i j t}= & \delta_{1}+\delta_{2} \ln \left(G D P_{i t} G D P_{j t}\right) \\
& +\delta_{3} \ln E N E X W_{i t}+\delta_{4} \ln G D I S_{i j t}+\delta_{5} \ln F D I_{i j t}++\delta_{6} \ln P R_{i t}+\varepsilon_{i j t}
\end{aligned}
$$

where ENEX indicates CIS's energy exports to China; GDP and ENEXW represent gross domestic product and the exporter's annual energy exports quantity to the world; FDI denotes China's FDI in the exporter; and $P R$ denotes the exporter's political risk.

In regard to the variables, it should be mentioned that many scholars have proven the linkages between the series and trade flows. For instance, the impact of GDP on trade between nations was verified by a number of researchers such as Popova and Rasoulinezhad (2016), Rasoulinezhad and Seong Kang (2016), and Rasoulinezhad (2017). The negative effects of geographical 
distance on trade flow are discussed in earlier studies (Rasoulinezhad and Jabalameli 2018, Brei and Von Peter 2018). Although Khoon Goh et al. (2013) demonstrated the influence of FDI on trade flows, Rotunno (2016) showed a linkage between political stability and trade flows. In addition, Shao et al. (2017) confirmed the relationship between total energy export volumes and energy export flows to a particular nation.

To conduct an estimation of coefficients, I ran the random effects (RE) estimator, which enabled me to include time-invariant variables (e.g. geographical distance) in the final results. Other panel estimators, such as fixed effects (FE) and FE Poisson maximum likelihood (ML), cannot estimate the coefficient of time-invariant variables (Cestepe et al. 2015). Therefore, the most appropriate estimator for my model is RE, which was structured as follows:

If the basic framework of the panel data is assumed to be:

$$
y_{i t}=x_{i t}^{\prime} \beta+z_{i}^{\prime} a+\varepsilon_{i t}=x_{i t}^{\prime} \beta+c_{i}+\varepsilon_{i t}
$$

where $x_{i t}$ contains regressors, $z_{i}^{\prime}$ a denotes the individual effect. If the unobserved individual heterogeneity can be considered to be uncorrelated with the included variables, Equation 2 can be rewritten as:

$$
y_{i t}=x_{i t}^{\prime} \beta+E\left[z_{i}^{\prime} \alpha\right]+\left\{z_{i}^{\prime} \alpha-E\left[z_{i}^{\prime} \alpha\right]\right\}+\varepsilon_{i t}=x_{i t}^{\prime} \beta+\alpha+u_{i}+\varepsilon_{i t}
$$

This RE equation expresses that $u_{i}$ is a group-specific random element (Greene 2011).

In addition, the Poisson pseudo-ML (PPML) estimator as proposed by Silva and Tenreyro (2006) is applied to conduct a robustness check for empirical estimations. If nonlinear least squares and optimize sums of squared residuals are assumed, the estimator of the model becomes as follows (Magerman et al. 2016):

$$
\widehat{\beta}=\arg \min S S R(\beta)=\arg \min \sum[Y-\exp (X \beta)]^{2}
$$

The first-order conditions for Equation 4 will be:

$$
\frac{\partial \hat{\beta}}{\partial \beta}=\sum[Y-\exp (X \beta)] \exp (X \beta) X=0
$$

where $Y-\exp (X \beta)$ is the model to be estimated and $\exp (X \beta) X$ indicates the weights of each observation in minimizing errors.

On the basis of Equation 5, the Poisson model is: 


$$
\operatorname{Pr}(Y=k \mid x)=\frac{\exp (-\lambda) \lambda^{k}}{k !}
$$

In Equation 6, $Y \geq 0$, and $Y \geq 0 Y \geq 0$. Hence, the ML optimization is specified as follows:

$$
\hat{\beta}=\arg \max [-\exp (X \beta)+Y(X \beta)-\ln (Y !)]
$$

and by conducting first-order conditions of Equation 7:

$$
\frac{\partial \hat{\beta}}{\partial \beta}=\sum[Y-\exp (X \beta)] X=0
$$

\section{Empirical Results}

\section{A. Preliminary tests}

To conduct correct and reliable panel estimations, various preliminary tests should be applied. The first preliminary test contains a cross-sectional dependence (CD) test to discover whether there are any breakpoints in our series. To this end, the Pesaran residual CD test is conducted by the pairwise correlation coefficients $\hat{\rho}_{i j}$ as follows:

$$
C D=\sqrt{\frac{2}{N(N-1)}} \sum_{i=1}^{N} \sum_{j=i+1}^{N} \sqrt{T_{i j}} \hat{\rho}_{i j}
$$

The results of this test, as listed in Table 3, depict the acceptance of the null hypothesis (no $\mathrm{CD}$ in residuals) at the $5 \%$ level. Hence, all variables show evidence of cross-sectional independence.

Table 3. Cross-sectional dependence test results

\begin{tabular}{ccc}
\hline Variables & Pesaran's CD test & $\boldsymbol{p}$-value \\
\hline$L E N E X$ & 26.11 & 0.32 \\
$L G D P$ & 28.49 & 0.58 \\
$L E N E X W$ & 19.24 & 0.18 \\
$L G D I S$ & 24.33 & 0.44 \\
$L F D I$ & 29.64 & 0.61 \\
$L P R$ & 31.93 & 0.73 \\
\hline
\end{tabular}

(Source) Author's compilation from Eviews 9.0. 
On the basis of the lack of $\mathrm{CD}$ of the variables, the common panel unit root tests, i.e., the ADF-Fisher Chi-square and the Phillips-Perron-Fisher Chi-square tests, can be used to analyze the stationarity of the time series data.

The results of applying the panel unit root test are reported in Table 4.

Table 4. Panel unit root test results

\begin{tabular}{|c|c|c|c|}
\hline Variable & ADF-Fisher Chi-square & Phillips-Perron-Fisher Chi-square & Stationary \\
\hline LENEX & $25.46[0.81]$ & $19.06[0.28]$ & No \\
\hline$D(L E N E X)$ & $185.03[0.00]$ & $218.47[0.00]$ & Yes \\
\hline$L G D P$ & $18.44[0.82]$ & $14.17[0.36]$ & No \\
\hline$D(L G D P)$ & $157.49[0.00]$ & $327.18[0.00]$ & Yes \\
\hline LENEXW & $10.61[0.72]$ & $16.22[0.93]$ & No \\
\hline$D(L E N E X W)$ & $277.01[0.00]$ & $316.37[0.00]$ & Yes \\
\hline$L G D I S$ & $9.82[0.24]$ & $17.36[0.00]$ & No \\
\hline$D(L G D I S)$ & $312.92[0.00]$ & $291.28[0.00]$ & Yes \\
\hline LFDI & $15.26[0.82]$ & $27.61[0.24]$ & No \\
\hline$D(L F D I)$ & $247.42[0.00]$ & $231.83[0.00]$ & Yes \\
\hline$L P R$ & $21.93[0.11]$ & $31.38[0.45]$ & No \\
\hline$D(L P R)$ & $288.52[0.00]$ & $321.72[0.00]$ & Yes \\
\hline
\end{tabular}

(Note) Numbers in brackets indicate $p$-values.

(Source) Author's compilation from Eviews 9.0.

On the basis of the results of two panel unit root tests, as shown in Table 4, all of the series are nonstationary at levels and stationary (rejecting the null hypothesis) at their first difference standing for $\mathrm{I}(1)$.

Next, a preliminary test is the cointegration test, which is performed by conducting the Pedroni panel cointegration test to explore a long-run equilibrium relationship between the series. The most significant results are reported in Table 5. The majority of all statistical tests reveal $\mathrm{H} 0$ rejection (no cointegration at the 5\% significance level). Hence, the results proved that there is evidence of a long-run relationship between variables.

Table 5. Pedroni panel cointegration test results

\begin{tabular}{ccccc}
\hline & Statistic & Prob. & Weighted statistic & Prob. \\
\hline Panel v-statistic & 1.83 & 0.42 & 0.21 & 0.27 \\
Panel rho-statistic & $-2.38^{*}$ & 0.00 & $-1.58^{*}$ & 0.00 \\
Panel PP-statistic & $-3.27^{*}$ & 0.00 & $-4.02^{*}$ & 0.00 \\
Panel ADF-statistic & $-3.66^{*}$ & 0.00 & $-3.52^{*}$ & 0.00 \\
Group rho-statistic & $-1.28^{*}$ & 0.05 & - & - \\
Group PP-statistic & $-2.49^{*}$ & 0.00 & - & - \\
Group ADF-statistic & $-4.10^{*}$ & 0.00 & - & - \\
\hline
\end{tabular}

(Note): * shows statistical significance at the $5 \%$ level.

(Source) Author's compilation from Eviews 9.0 
In addition, the Kao cointegration test is employed to conduct a robustness check. Table 6 presents the results of the Kao test, which rejected the $\mathrm{H} 0$ of no cointegration at a 0.05 significance level.

Table 6. Kao residual cointegration test

\begin{tabular}{ccc}
\hline \multicolumn{4}{c}{ Series: } & LENEX & LGDP & LENEXW & LGDIS LFDI LPR & \\
\hline ADF & t-statistic & Probability \\
& 4.329 & 0.02 \\
\hline
\end{tabular}

(Note) ENEX indicates CIS's energy exports to China. GDP and ENEXW show the exporter's GDP and the exporter's annual energy exports quality to the world. GDIS is geographic distance from China, whereas FDI and $P R$ show foreign direct investment and the exporter's political risk, respectively.

(Source) Author's compilation from Eviews 9.0.

\section{B. Empirical econometric estimation}

On the basis of cointegration test findings that support the existence of a long-run linkage between the series in our panel equations, the panel data estimation approach, i.e., the RE estimation, is applied to reveal the effects of regressors on the CIS's energy exports to China. Because my model contains geographic distance, which does not change between countries over time, I used this type of panel data estimation. Furthermore, the PPML is also conducted as a robustness check.

The findings of conducting RE and FMOLS estimations are presented in Table 7.

Table 7. Panel estimation results

\begin{tabular}{|c|c|c|c|c|c|c|}
\hline \multirow{2}{*}{$\begin{array}{l}\text { Dependent } \\
\text { variable }\end{array}$} & \multirow{2}{*}{$\begin{array}{l}\text { Independent } \\
\text { Variables }\end{array}$} & \multicolumn{2}{|c|}{ RE } & \multicolumn{2}{|c|}{ PPML } & \multirow{2}{*}{$\begin{array}{l}\text { Mean of } \\
\text { coefficients }\end{array}$} \\
\hline & & Coefficient & $P$-value & Coefficient & $P$-value & \\
\hline \multirow{5}{*}{$\begin{array}{c}\text { CIS's } \\
\text { energy } \\
\text { exports to } \\
\text { China }\end{array}$} & The exporter's GDP & 0.42 & 0.00 & 0.36 & 0.00 & 0.39 \\
\hline & $\begin{array}{l}\text { The exporter's annual energy exports } \\
\text { quantity to the world }\end{array}$ & -0.23 & 0.02 & -0.33 & 0.00 & -0.28 \\
\hline & Geographic distance from China & -0.12 & 0.00 & -0.27 & 0.00 & -0.19 \\
\hline & China's direct investment in the exporter & 0.38 & 0.04 & 0.68 & 0.01 & 0.53 \\
\hline & The exporter's political risk & 0.23 & 0.00 & 0.41 & 0.00 & 0.32 \\
\hline
\end{tabular}

(Source) Author's compilation from Stata 15 and Eviews 9.0.

My main findings, also listed in Table 7, are as follows:

i. The estimation findings reveal that economic size, as measured by GDP, has significant positive impact on CIS energy exports to China. A $1 \%$ increase in the energy exporter's GDP in the CIS region leads to an increase in energy exports to China by nearly $0.39 \%$ (average of the coefficients estimated by FE and PPML). This finding is aligned with Rasoulinezhad and Wei (2017), who proved the positive effect of GDP on China's energy imports from 
OPEC member countries. On one hand, any increase in the GDP of energy producers leads to an improvement in their oil and gas sectors by increased investment in infrastructure to develop their production and export capacities. On the other hand, the growth of China's GDP means there is a higher energy need in industry and transportation in particular.

ii. In regard to main variables, the quantity of the CIS's annual energy exports to countries other than China has a significant negative effect on China's energy imports from the CIS. A $1 \%$ increase in the CIS's energy exports to other countries leads to an approximately $0.28 \%$ reduction in China's energy imports from the CIS. This result is in line with Osakwe et al. (2018), who argue that export diversification can balance export volumes among various trade partners.

iii. In regard to geographic distance acting as a proxy for transportation cost, the negative sign of its coefficient indicates that geographical distance may decelerate energy trade flows running from the CIS to China. A $1 \%$ increase in this variable reduces Chinese energy imports from the CIS by about $0.19 \%$. This finding is in line with Hallefjord and Jornsten (1986), Luoma et al. (1994), Fratianni and Kang (2006), Huang (2007), Ekanayake (2010), Tamagawa (2011), Håkanson (2014), Brei and Von Peter (2018), and Molaepour et al. (2018), who demonstrated the negative effect of distance in trade flows between nations.

iv. The estimated results affirm the significant positive coefficient of China's FDI in CIS member states. A $1 \%$ increase of direct investment by China into the CIS may accelerate energy export volumes by nearly $0.53 \%$. This result corroborates the work of Santiago (1987), Dritsaki and Stiakakis (2014), and Sunde (2017), who discovered a positive relationship between FDI and trade flows, but it contradicts the work of Kiran (2011) who asserted that there exists no evidence of causality between FDI and trade.

v. Among all of my regressors, the sign of the coefficient for PR is most interesting. A $1 \%$ increase in the CIS's PR may lead to an approximately $0.32 \%$ increase in China's energy imports from this region. This finding indicates that China's good diplomatic relationships with CIS member states and its diplomatic power to engage in any PRs in the CIS lead to an improvement in its energy trade relationship with CIS states.

\section{Conclusions}

The division of the USSR into 15 countries (known as the CIS), as well as China's energy-based economy and energy demand acceleration since the beginning of the $2000 \mathrm{~s}$, has given rise to the forging of the CIS-China energy ties and caused a special energy trading pattern running from CIS member states to China. This unique energy trading pattern may 
be considered a key instrument to encourage the economic integration of China with CIS states. In this paper, I sought to empirically discover what determines China's energy importing pattern from the CIS in order to uncover policies that will further China-CIS economic integration. To this end, I used the model of Shao et al. (2017) with datasets over a period between 2000 and 2017. The conducted variables in this study were based on the TPG factors proposed by the model of Shao et al.

The main findings of my paper reveal that a $1 \%$ increase in the energy exporter's GDP in the CIS region leads to an increase in energy exports to China by nearly $0.39 \%$. In other words, by developing the economic size of CIS nations, inward FDI from other nations in their energy projects may result in an increase in energy production capacity and a higher level of trade flows into these nations. As Pan and Nguyen (2018) mention, economic growth and exports are interrelated. Furthermore, the annual amount of energy the CIS exports to countries other than China has a significant negative effect on China's energy imports from the CIS. In fact, because of limitations on increasing energy production (Owusu and Asumadu-Sarkodie 2016), a greater distribution of produced energy sources in the CIS to nations other than China may lead to a reduction of the CIS's energy exports to China. It can be concluded that by any increase in the diversification of the CIS's energy exporting markets, China's energy imports from the CIS may decrease, which ultimately means that China will have higher energy security risks. Hence, de-diversification in CIS energy exporting markets may be considered to be a key to Chinese energy security. In regard to geographic distance, findings indicated a negative sign of its coefficient, meaning that geographical distance may decelerate energy trade flows running from the CIS to China. Our results regarding the negative linkage between distance and trade flows is supported by a number of earlier studies such as Rasoulinezhad and Seong Kang (2016), Rasoulinezhad and Wei (2017), Liaqat et al. (2018), and Rasoulinezhad (2018). Other results of this study include the fact that China's FDI in CIS states can determine and accelerate energy export flows running from the CIS to China. Our findings corroborated the results of Feng et al. (2009) and Doku et al. (2017), who expressed the importance of China's FDI into oil and gas field projects in Russia, the biggest member of the CIS. Finally, our major findings verified evidence of a positive relationship between PR in the CIS and energy importing flows to China. This result is in line with Peyrouse (2016), who posited that China, with its remarkable diplomacy, has increased its presence and influence with CIS member states. This solid political tie led to the development of a strong economic and trade relationship between China and the CIS, which cannot be easily destroyed even considering CIS's political instability.

On the basis of the achieved coefficients of TPG factors in the panel data model framework, the rank of influential factors (according to their magnitude) on China's energy import flows from the CIS is as Figure 3: 
Figure 3. Rank of influential TPG factors on China's energy import flows from the CIS

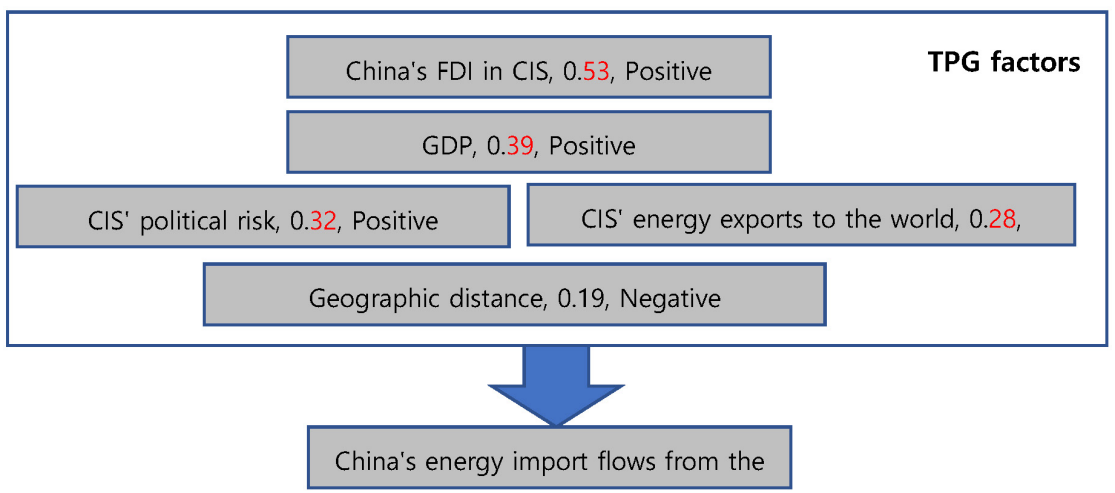

(Source) Author's compilation.

On the basis of the empirical results, it can finally be concluded that lowering PR, increasing capital flows, empowering the national economies of CIS members, and improving transportation routes in the region are all essential factors for achieving a higher degree of economic integration between China and the CIS. Among these factors, increasing China's FDI flows in this region and increasing the GDP of CIS members play important roles in forging a stronger China-CIS economic integration tie.

Last, I present some recommendations for future studies related to economic integration based on energy trade flow patterns between China and the CIS. The current situation of political tension between Russia and Ukraine may be an influential factor in the future of CIS-China energy trade flows. Hence, considering it as a variable might be a good way to attain better academic results. Furthermore, the long-run energy strategies of China, such as the Energy Production and Consumption Revolution Strategy (2016 2030) and long-term economic and social development targets such as China Dream (Li et al. 2018), may negatively affect China's nonrenewable energy imports from the CIS in terms of reducing $\mathrm{CO}_{2}$ emissions. Therefore, investigating the effects of China's long-run energy strategies would be of interest to many policymakers.

\section{References}

Adams, F. G., and Shachmurove, Y. (2008). "Modeling and forecasting energy consumption in China: Implications for Chinese energy demand and imports in 2020." Energy Economics 30, no. 3, 1263-1278. Aizenman, J., and Noy, I. (2006). "FDI and trade-Two-way linkages?." The Quarterly Review of Economics and Finance 46, no. 3, 317-337.

Alesina, A., Spolaore, E., and Wacziarg, R. (2000). "Economic integration and political disintegration." 
American Economic Review 90, no. 5, 1276-1296.

Ali, L., Mi, J., Shah, M., Shah, S. J., Khan, S., Ullah, R., and Bibi, K. (2018). "Local residents' attitude towards road and transport infrastructure (A case of China Pakistan economic corridor)." Journal of Chinese Economic and Foreign Trade Studies 11, no. 1, 104-120.

Apergis, N., and Payne, J. E. (2010). "The emissions, energy consumption, and growth nexus: Evidence from the commonwealth of independent states." Energy Policy 38, no. 1, 650-655.

Baldwin, R. E., and Venables, A. J. (1995). "Regional Economic Integration." Handbook of International Economics (Chapter 31) 3, 1597-1644.

Black, W. R. (1973). “An analysis of gravity model distance exponents.” Transportation 2, 299-312.

Bond, E. W., Jones, R. W., Ping, W. (2005). "Economic takeoffs in a dynamic process of globalization." Review of International Economics 13, no. 1, 1-19.

Braga-Alves, M. (2018). "Political risk and the equity trading costs of cross-listed firms." The Quarterly Review of Economics and Finance 69, 232-244.

Brei, M., and Von Peter, G. (2018). "The distance effect in banking and trade." Journal of International Money and Finance 81, 116-137.

Cestepe, H., Yildirim, E., and Bahtiyar, B. (2015). "The impact of trade liberalization on the export of MENA countries to OECD trade partners." Procedia Economics and Finance 23, 1440-1445.

Chomakhidze, D., Tskhakaia, K., and Shamaevi, D. (2017). "Twenty years' experience of the regulation of energy in Georgia." Energy Procedia 128, 130-135.

Chen, Y. (2015). "The distance-decay function of geographical gravity model: Power law or exponential law?." Chas, Solitons \& Fractals 77, 174-189.

Chenard, S. (1994). "Future for CIS space industry." Space Policy 10, no. 3, 236-240.

Davis, J. R. (1997). "The creation of an agricultural free trade area in the CIS: arguments against following the CAP model." Food Policy,22, no. 1, 11-16.

Dimic, N., Orlov, V., and Poljak, V. (2016). "The effect of political risk on currency carry trades." Finance Research Letters 19, 75-78.

Doku, I., Akuma, J., Owusu-Afriyie, J. (2017). "Effect of Chinese foreign direct investment on economic growth in Africa." Journal of Chinese Economic and Foreign Trade Studies 10, no. 2, 162-171.

Dong, X., and Kong, Zh. (2016). "The impact of China's natural gas import risks on the national economy." Journal of Natural Gas Science and Engineering 36, no. A, 97-107.

Dritsaki, Ch., and Stiakakis, E. (2014). "foreign direct investments, exports, and economic growth in croatia: A time series analysis." Procedia Economic and Finance 14, 181-190.

Ekanayake, E. M., Mukherjee, A., and Veeramacheneni, B. (2010). "Trade blocks and the gravity model: A study of economic integration among Asian developing countries." Journal of Economic Integration 25, no. 4, 627-643.

Feng, Y., Sun, Y., and Walton, J. C. (2009). "Foreign direct investment in Russia and lessons for China." The Chinese Economy 42, no. 3, 78-93.

Fratianni, M., and Kang, H. (2006). "Heterogeneous distance-elasticities in trade gravity models." Economics Letters 90, no. 1, 68-71.

Ge, F., and Fan, Y. (2013). "Quantifying the risk to crude oil imports in China: An improved portfolio 
approach.” Energy Economics 40, 72-80.

Golobokov, A. S. (2015). "Various forms and mechanisms of Chinese-Russian cooperation in the energy sphere and the role of non-governmental structures." Pacific Science Review B: Humanities and Social Sciences 1, no. 1, 45-48.

Greene, W. (2011). Econometric Analysis, $7^{\text {th }}$ ed. Prentice Hall: USA.

Hakanson, L. (2014). "The role of psychic distance in international trade: A longitudinal analysis." International Marketing Review 31, no. 3, 210-236.

Hallefjord, A., and Jornsten, K. (1986). "Gravity models with multiple objectives- Theory and applications." Transportation Research Part B: Methodological 20, no. 1, 19-39.

He, J., Gong, X., and Wang, Sh. (2009). "Causality Relationship between the US-China Trade Balance and the US and Japan Direct Investment in China." Systems Engineering-Theory \& Practice 29, no. 6, 6-18.

Hirschhausen, Ch., and Waelde, Th. (2001). "The End of Transition: An Institutional Interpretation of Energy Sector Reform in Eastern Europe and the CIS.” MOST: Economic Policy in Transitional Economies 11, no. 1, 93-110.

Howell, L., and Chaddick, B. (1994). "Models of political risk for foreign investment and trade: An assessment of three approaches." The Columbia Journal of World Business 29, no. 3, 70-91.

Huang, R.R. (2007). "Distance and trade: Disentangling unfamiliarity effects and transport cost effects." European Economic Review 51, no. 1, 161-181.

Jabalameli, F., and Rasoulinezhad, E. (2018). "BRICS-United Nations regional groups' trade patterns: A panel-gravity approach." Journal of Chinese Economic and Foreign Trade Studies 11, no. 2, 151-179.

Kakachia, K. K. (2011). "Challenges to the South Caucasus regional security aftermath of Russian-Georgian conflict: Hegemonic stability or new partnership?.” Journal of Eurasian Studies 2, no. 1, 15-20.

Kandogan, Y. (1999). "Lingering effects of central planning on trade? Evidence from current CIS trade patterns." Weltwirtschaftliches Archiv 135, no. 3, 501-521.

Karatayev, M., and Clarke, M. L. (2014). "current energy resources in kazakhstan and the future potential of renewables: A review." Energy Procedia 59, 97-104.

Khoon Goh, S., Nyen Wong, K., and Yean Tham, S. (2013). Trade "linkages of inward and outward FDI: Evidence from Malaysia." Economic Modelling 35, 224-230.

Kiran, B. (2011). "Causal Links between Foreign Direct Investment and Trade in Turkey." International Journal of Economics and Finance 3, no. 2, 150-158.

Korhan, G., Amin, M., Taspinar, N. (2015). "the relationship among international trade, financial development and economic growth: The case of pakistan." Procedia Economics and Finance 25, 489-496.

Kubicek, P. (2009). "The commonwealth of independent states: An example of failed regionalism?." Review of International Studies 32, 237-256.

Li, H., Sun, R., Dong, K., Dong, X., Zhou, Zh., and Leng, X. (2017). "Selecting China's strategic petroleum reserve sites by multi-objective programming model." Petroleum Science 14, no. 3, 622-635.

Li, J., Ma, Zh., Zhang, Y., and Wen, Zh. (2018). "Analysis on energy demand and CO2 emissions in China following the Energy Production and Consumption Revolution Strategy and China Dream 
target." Advances in Climate Change Research 9, no. 1, 16-26.

Lin, B., and Wang, T. (2012). "Forecasting natural gas supply in China: Production peak and import trends." Energy Policy 49, 225-233.

Liu, M., and Pistorius, T. (2012). "Coping with the energy crisis: Impact assessment and potentials of non-traditional renewable energy in rural Kyrgyzstan.” Energy Policy 44, 130-139.

Liu, X., Wang, Ch., and Wei, Y. (2001). "Causal links between foreign direct investment and trade in China." China Economic Review 12, no. 2-3, 190-202.

Luoma, M., Mikkonen, K., and Palomaki, M. (1993). "The threshold gravity model and transport geography: How transport development influences the distance-decay parameter of the gravity model." Journal of Transport Geography 1, no. 4, 240-247.

Magerman, G., Studnicka, Z., and Van Hove, J. (2016). "Distance and border effects in international trade: A comparison of estimation methods." Economics 10, no. 18, 1-31.

Malle, S. (2017). "Russia and China in the 21st century: Moving towards cooperative behavior." Journal of Eurasian Studies 8, no. 2, 136-150.

Melitz, J. (2007). "North, South and distance in the gravity model." European Economic Review 51, no. 4, 971-991.

Molaepour, M., Mahdaviadeli, M., and Sabahi, A. (2018). "Iran's economic integration into the CIS." Quarterly Journal of Economic Research and Policies 25, no. 84, 257-290.

Newnham, R. (2011). "Oil, carrots, and sticks: Russia's energy resources as a foreign policy tool." Journal of Eurasian Studies 2, no. 2, 134-43.

Nurgaliyeva, L. (2016). 'Kazakhstan's economic soft balancing policy vis-à-vis Russia: From the Eurasian Union to the economic cooperation with Turkey." Journal of Eurasian Studies 7, no. 1, 92-105.

Oh, Ch., and Reuveny, R. (2010). "Climatic natural disasters, political risk, and international trade." Global Environmental Change 20, no. 2, 243-254.

Orlov, A. (2016). "The strategic implications of the second Russia-China gas deal on the European gas market." Energy Strategy Reviews 13-14, 1-10.

Osakwe, P. N., Santos-Paulino, A. U., and Dogan, B. (2018). "Trade dependence, liberalization, and exports diversification in developing countries." Journal of African Trade 5, no. 1-2, 19-34.

Owusu, P. A., and Asumadu-Sarkodie, S. (2016). "A review of renewable energy sources, sustainability issues and climate change mitigation." Cogent Engineering 3, no. 1. doi.org/10.1080/23311916.2016.11 67990

Pan, M., and Nguyen, H. (2018). "Export and growth in ASEAN: Does export destination matter?" Journal of Chinese Economic and Foreign Trade Studies 11, no. 2, 122-131.

Peyrouse, S. (2016). "Discussing China: Sinophilia and Sinopobia in Central Asia." Journal of Eurasian Studies 7, no. 1, 14-23.

Popova, L., and Rasoulinezhad, E. (2016). "Have sanctions modified Iran's trade policy? An evidence of Asianization and De-Europeanization through the gravity model." Economies 4, no. 4, 1-24.

Quang, L., and Xing-Kang, Q. (2009). "World energy structure and choices of Chinese energy strategy." Procedia Earth and Planetary Science 1, no. 1, 1723-1729.

Rasoulinezhad, E. (2017). "China's foreign trade policy with OPEC member countries.” Journal of Chinese 
Economic and Foreign trade studies 10, no. 1, 61-81.

Rasoulinezhad, E. (2018). "A new evidence from the effects of Russia's WTO accession on its foreign trade.” Eurasian Economic Review 8, no. 1, 73-92.

Rasoulinezhad, E. (2019). "analyzing energy export patterns from the commonwealth of independent states to China: New evidence from gravity trade theory." The Chinese Economy 52, no. 3, 279-294.

Rasoulinezhad, E., and Jabalameli, F. (2018). "Do BRICS countries have similar trade integration patterns?." Journal of Economic Integration 33, no. 1, 1011-1045.

Rasoulinezhad, E., and Jabalameli, F. (2019). "Russia-EU gas game analysis: Evidence from a new proposed trade model." Environmental Science and Pollution Research. doi.org/10.1007/s11356-019-05681-2

Rasoulinezhad, E., and Seong Kang, G. (2016). "A panel data analysis of South Korea's trade with OPEC member countries: The gravity model approach.” Iranian Economic Review 20, no. 2, 203-224.

Rasoulinezhad, E., Taghizadeh-Hesary, F., Yoshino, N., and Sarker, T. (2019). Russian Federation-East Asia Liquefied Natural Gas Trade Patterns and Regional Energy Security. ADBI Working Paper 965. Tokyo: Asian Development Bank Institute.

Rasoulinezhad, E., and Wei, W. (2017). "China's trade with OPEC member countries: A panel-gravity model approach." The Chinese Economy 50, no. 5, 339-355.

Roberts, M., and Werheim, P. (2001). "Regional trade agreements and WTO accession of CIS countries." Intereconomics 36, no. 6, 315-323.

Rotunno, L. (2016). "Political stability and trade agreements: Evidence for endgame FTAs." European Journal of Political Economy 45, 133-148.

Santiago, C. E. (1987). "The impact of foreign direct investment on export structure and employment generation." World Development 15, no. 3, 317-328.

Sergi, B. S. (2018). "Putin's and Russian-led Eurasian Economic Union: A hybrid half-economics and half-political "Janus Bifrons"." Journal of Eurasian Studies 9, no. 1, 52-60.

Shao, Y., Qiao, H., and Wang. (2017). "What determines China's crude oil importing trade patterns: Empirical evidences from 55 countries between 1992 to 2015." Energy Policy 109, 854-862.

Silva, J. S., and Tenreyro, S. (2006). "The log of gravity." The Review of Economics and statistics 88, 641-658.

Soete, S., and Van Hove, J. (2017). "dissecting the trade effects of europe's economic integration agreements." Journal of Economic Integration 32, no. 1, 193-243.

Sunde, T. (2017). "Foreign direct investment, exports and economic growth: ADRL and causality analysis for South Africa." Research in International Business and Finance 41, 434-444.

Szkorupova, Z. (2014). "a causal relationship between foreign direct investment, economic growth and export for slovakia." Procedia Economics and Finance 15, 123-128.

Taghizadeh-Hesary, F., Rasoulinezhad, E., Yoshino, N. (2019). "Energy and food security: Linkages through price volatility.” Energy Policy 128, 796-806. doi.org/10.1016/j.enpol.2018.12.04

Taghizadeh-Hesary, F., Yoshino, N., Abdoli, G., and Farzinvash, A. (2013). "An estimation of the impact of oil shocks on crude oil exporting economies and their trade partners." Frontiers of Economics in China 8, no. 4, 571-591. doi.org/10.3868/s060-002-013-0029-3

Taghizadeh-Hesary, F., Yoshino, N., Chang, Y., and Rillo, A.D. (2019). "Introduction.” Achieving Energy Security in Asia: Diversification, Integration and Policy Implications. Eds. F. Taghizadeh-Hesary, 
N. Yoshino, Y. Chang, A.D. Rillo. Singapore: World Scientific.

Tamagawa, H. (2011). "The Implications of Using a Gravity Model to Determine Territory in a Circular Domain." Procedia-Social and Behavioral Sciences 21, 167-176.

Valigholizadeh, A., Zaki, Y., and Zoghi Barani, K. (2013). "An analytical study of geopolitical consequences of normalization of Turkish-Armenian relations." Journal of Eurasian Studies 4, no. 2, 197-206.

Vidadili, N., Suleymanov, E., Bulut, C., and Mahmudlu, C. (2017). "Transition to renewable energy and sustainable energy development in Azerbaijan." Renewable and Sustainable Energy Reviews 80, 1153-1161.

Zahanogo, P. (2016). "Trade and economic growth in developing countries: Evidence from sub-Saharan Africa." Journal of African Trade 3, no. 1-2, 41-56.

Zou, C., Zhao, Q., Chen, J., Li, J., Yang, Zh., Sun, Q., Lu, J., and Zhang, G. (2018). "Natural gas in China: Development trend and strategic forecast." Natural Gas Industry B 5, no. 4, 380-390. 